\title{
LEARNING FROM THE BEST: READING LITERACY DEVELOPMENT PRACTICES AT A HIGH-PERFORMING PRIMARY SCHOOL
}

\author{
Lisa Zimmerman, University of South Africa
}

While it is of utmost importance to scrutinise reading literacy development practices at South African schools where learners are failing to progress in their reading development in the primary school years, it is also beneficial to explore the practices and processes in schools where learners successfully develop reading literacy in depth. In this paper, the processes and practices for reading literacy development in a school with a high Grade 4 class average performance from the Progress in International Reading Literacy Study (PIRLS) 2006 are explored in detail. The school had the highest Grade 4 class average performance of six purposively selected case study schools with varying contexts and performance levels aligned to achievement benchmarks from the PIRLS 2006. Data were collected from multiple sources for this case study as part of a larger mixed methods study. In this article, however, only interviews with teachers and the Foundation and Intermediate Phase literacy leaders at the school are reported and reflected on. Specifically, school-level reading literacy development initiatives in the form of planning, monitoring and collaboration, across-grade and -phase reading literacy programme coordination, and parental involvement strategies are discussed. Socioeconomic realities and historical inequalities play a huge role in learner performance across schools in South Africa. Although this specific school, which features pre-primary, primary and high school grades, is highly privileged, which likely also plays a role in the learners' achievement, the reading literacy development processes and practices implemented at the school can be learnt from and applied in less privileged contexts.

\section{INTRODUCTION AND BACKGROUND}

South African learners have reading problems, regardless of which language they read in (Howie et al., 2008; Howie, Van Staden, Tshele, Dowse \& Zimmerman, 2012). Without strong reading literacy development, learners will battle to be successful in their educational progression throughout schooling, which has dire consequences for their future prospects. Reading therefore needs to be a central school activity (Pretorius \& Lephalala, 2011: 2). In South Africa, learner achievement results in numerous studies attest to the fact that reading literacy development has not been given the status it so desperately needs in schools (Howie et al., 2008, 2012). As summarised by Pretorius and Klapwijk (2016: 1-2), there have been a number of policy initiatives aimed at rectifying problems with reading development in schools, as well as major curricular changes (Department of Basic Education (DBE), 2011). However, the impact thereof has not yet shown any fruition in terms of major improvement as measured by national and international tests of learner reading literacy achievement (Howie et al., 2012). Moreover, without grassroots impetus and understanding of the importance of reading literacy development by teachers and managers in schools, there is unlikely to be any significant change to the status quo. 
While a number of studies have begun to disentangle the reasons for learners' poor reading literacy development in South African primary schools (see Klapwijk, 2012; van Staden \& Bosker, 2014; Zimmerman \& Smit, 2014; Zimmerman, Howie \& Smit, 2011, as examples), there is still much need for further research. This is particularly because, although a great deal of research exists on learners' poor reading literacy levels, there is little research on instructional practices and management of reading in schools (Zimmerman, 2011; Pretorius \& Klapwijk, 2016). A methodological avenue not often utilised in the scholarly literature surrounding this issue is that of in-depth qualitative case studies to lead to a better understanding of how reading is developed in South African schools, as well as the successes and challenges experienced (Zimmerman \& Smit, 2016). Certainly, there would seem to be minimal studies that report on exemplary schools in terms of reading literacy development. In 2007, Sailors, Hoffman and Matthee (2007: 368) confirmed that there was no evidence of South African research documenting the existence of effective or outlier schools where learners from low-income communities achieved good literacy outcomes in South Africa at the time. In their study, Sailors et al. (2007) thus focused on seven high-performing schools serving low-income learners involved in a long-term intervention, but this was the only study of this nature found in the literature prior to the study reported in this paper. The focus of South African research has often been on the problems at schools where the majority of learners fail to develop the reading literacy levels needed for optimal schooling progress and reporting on small-scale interventions. Although this is understandable under the prevailing circumstances and although this information is needed too, not enough opportunities have been sought to learn from schools where learners do progress optimally in their reading literacy development in the primary school years.

There is no denying that the situation in South African schools is complex, with historic inequalities, high levels of poverty, low parental literacy levels, lack of educational resources and teachers without the educational background to understand how to develop learners' reading literacy contributing to the problem (Pretorius \& Klapwijk, 2016; Spaull, 2013; Zimmerman, 2011). Poor school management of the literacy programme may be a specific issue leading to non-conducive professional organisation and environments for teaching reading literacy (Zimmerman et al., 2011).

Against these background factors which could play a role in a large number of schools, one may be doubtful of the relevance of exploring the processes and practices for reading literacy development in a highly privileged, high-performing South African school. This is due to the potential impact of high learner socioeconomic status and high levels of school resource availability on learner achievement. It may also be because affluent learners tend to perform better on standardised tests even if qualities of teaching expertise are absent in the instruction they receive (Collins Block, Oakar \& Hurt, 2002: 183).

The school under exploration was an outlier from the majority of the sampled schools as one of the schools with the highest Grade 4 class average achievement profiles for the Progress in International Reading Literacy Study (PIRLS) 2006. There were no sampled schools from low-income communities that had similar class averages. A strength of the overall study (Zimmerman, 2011) wherein this highly privileged school was explored is that it also investigated a range of school-situations via comparative case studies to learn what is possible under 'normal' circumstances (Levin, 2006: 401) reflective of the South African education landscape. When these schools, selected according to their Grade 4 learners' class average in the PIRLS 2006, were compared, it showed the discrepancies in practices between highly 
privileged and less privileged schools (see Zimmerman, 2014; Zimmerman \& Smit, 2014, 2016; Zimmerman et al., 2011). This highly privileged school is important, not only to demonstrate what learners can achieve given multiple teaching resources, but more importantly as an illustration of exemplary management structures employed for reading development - practices and structures which can be transferred to less privileged teaching environments with minimal resource expenditure, but with a focus on teacher and school manager skill development.

This paper is thus aimed at scrutinising this highest-performing school in much more detail than cross-case comparison of the range of cases in other papers has allowed. Moreover, additional reading literacy programme management data collected from the Foundation Phase of this school which has not been reported previously is considered as well. The aim of this paper is therefore to bring together the data for the single case into a holistic description to allow for the rich account expected of an illustrative case. The characteristics of exemplary schools with optimal reading literacy development practices are first discussed. A brief outline of the research design and methodology as it relates to this single case lifted from the larger mixed method study involving further analysis related to the PIRLS 2006 (Zimmerman, 2011 ) is then provided. The structure of the reading literacy programme at the highperforming school in the form of findings is then outlined and conclusions and recommendations are made.

\section{THE CHARACTERISTICS OF EFFECTIVE SCHOOLS WITH HIGH LEARNER ACHIEVEMENT}

Characteristics of effective schools with high learner achievement are well documented in the international scholarly literature base. A combination of reasons is given for variation in learners' achievement averages across different schools. Schools with high learner achievement averages may be located in privileged areas where the assumption is that parents care about their children's education, help their children learn to read as early as feasible, show interest in schoolwork and provide access to books at home. Such schools may also be better equipped than schools with low achievement and may have good teachers as well. Finally, these schools may be well-managed, with the principals helping teachers through enthusiasm and creative leadership in terms of school pedagogy (Postlethwaite \& Ross, 1992: 9-10).

According to Lockheed, Verspoor et al. (1991: 43-44), effective schools manage to transform their given education inputs into children's learning, in spite of poor conditions in some instances. Moreover, such schools have an orderly school environment, clear goals, high expectations, a sense of community and strong instructional leadership. The academic emphasis of these schools is evident in high expectations and defined goals for academic achievement; a curriculum which is focused on teaching both basic and complex goals; the concentration of available resources and their operations on achieving these goals; sufficient time for teaching these goals; coordination of instruction across grade levels; and continuous monitoring of learner progress to check whether goals have been achieved. In consideration of strong instructional leadership, the principal is highly visible at school and devotes considerable time to coordinating and managing instruction. A common sense of commitment and collegiality among staff is evident and a participatory management style is employed (Lockheed et al., 1991: 43-44). 
Similarly, in their review of the literature, Sailors et al. (2007: 368) indicate that effective schools with high reading achievement which serve low-income learners have a number of features, including a clear school mission; effective instructional leadership and practices; high expectations; a safe, orderly and positive environment; ongoing curriculum improvement; maximum use of instructional time; frequent monitoring of learner progress; and positive home-school relationships.

In a report to the South African Minister of Education on schools that work, Christie, Butler and Potterton (2007: 30-31) noted the international literature base on effective schools which could guide South African education, with the caveat that change depends on the capacity and will of teachers and school leadership. Sailors et al. (2007: 368), in noting the apparent nonavailability of South African educational effectiveness research for reading literacy, investigated the qualities of seven high-performing primary schools in reading literacy serving low-income South African learners. These schools had participated in a five-year intervention focused on school-improvement initiatives, training teachers in effective teaching strategies and providing classrooms with high-quality learning materials. Five broad themes linked to these high-performing schools were identified: (1) a safe, orderly, and positive learning environment; (2) strong leaders; (3) excellent teachers (competent, committed, caring, collaborative); (4) a shared sense of competence, pride and purpose for the school; and (5) high levels of school and community involvement (Sailors et al., 2007: 376). The findings from the intervention study confirmed that these local effective schools had similar attributes to their overseas counterparts from the long-established school effectiveness literature. Even so, the Sailors et al. (2007) study reveals little insight into what makes a school effective in terms of reading literacy development practices in particular.

\section{RESEARCH DESIGN AND METHODS}

The sampling strategy for the overall mixed-method study played a crucial role in the determination of the case study school's status as a school with successful reading literacy development, which is the focus of this article. In this section, sampling for the purposefully selected high-performing school is discussed and then the data collection strategies and analysis processes for this case are outlined.

\section{Sampling for purposively selected high performing case study school}

The case study data for the high-performing school were collected as part of a larger, partially mixed, sequential, equal-status mixed-methods design aimed at obtaining further insights from the implementation of the PIRLS 2006 in South Africa (Zimmerman, 2011). PIRLS is an international comparative assessment where reading literacy tests are completed by Grade 4 learners, and background questionnaires are administered to Grade 4 learners, parents, teachers and principals nationally in a survey (Mullis, Martin, Kennedy \& Sainsbury, 2006). The high-performing school was one of six schools purposively selected from a national sample of 429 schools which participated in the PIRLS 2006, with the aim of qualitative exploration of school and classroom-level reading literacy practices aligned to language and achievement profiles utilising a comparative, illustrative case study approach.

To assist in selection of the cases, international benchmarks from the PIRLS were used and national benchmarks were created ${ }^{\mathrm{i}}$, ii based on the national distribution of performance. For the PIRLS 2006 main study, learners' performance ranges were aligned with four set 
benchmarks along the scoring scale, namely, the Low (400), Intermediate (475), High (550) and Advanced (625) benchmarks. The learners who were able to reach the higher benchmarks also displayed the knowledge and skills for the lower benchmarks (Howie et al., 2008). Table 1 outlines the median percentage of Grade 4 learners reaching the international benchmarks for PIRLS 2006 internationally as well as in South Africa (Howie et al., 2008; Zimmerman et al., 2011).

Table 1: Percentage of South African learners at the PIRLS 2006 international benchmarks compared to learners internationally (Zimmerman, 2011: 35)

\begin{tabular}{|c|c|c|c|}
\hline $\begin{array}{c}\text { PIRLS 2006 } \\
\text { international } \\
\text { benchmarks }\end{array}$ & Benchmark descriptions & $\begin{array}{c}\text { Grade } 4 \\
\text { learners } \\
\text { internationally } \\
\text { reaching } \\
\text { benchmarks } \\
\text { Median \% } \\
\end{array}$ & $\begin{array}{c}\text { South African } \\
\text { Grade } 4 \\
\text { learners } \\
\text { reaching } \\
\text { benchmarks } \\
\text { Median \% (SE) }\end{array}$ \\
\hline $\begin{array}{c}\text { Low } \\
(400-474)\end{array}$ & $\begin{array}{l}\text { Basic reading skills and strategies } \\
\text { (retrieve explicitly stated information } \\
\text { in texts and answers some questions } \\
\text { seeking straightforward inferences). }\end{array}$ & 94 & $13(0.5)$ \\
\hline $\begin{array}{c}\text { Intermediate } \\
(\mathbf{4 7 5 - 5 4 9 )}\end{array}$ & $\begin{array}{l}\text { Some reading proficiency and can } \\
\text { understand the plot at a literal level } \\
\text { and can make some inferences and } \\
\text { connections across texts. }\end{array}$ & 76 & $7(1.1)$ \\
\hline $\begin{array}{c}\text { High } \\
(550-624)\end{array}$ & $\begin{array}{l}\text { Competent readers who have the } \\
\text { ability to retrieve significant details } \\
\text { embedded across the text and can } \\
\text { provide text-based support for } \\
\text { inferences. }\end{array}$ & 41 & $3(2.0)$ \\
\hline $\begin{array}{c}\text { Advanced } \\
(625+)\end{array}$ & $\begin{array}{l}\text { Respond fully by means of their } \\
\text { integration of information across } \\
\text { relatively challenging texts and the } \\
\text { provision of full text-based support in } \\
\text { their answers. }\end{array}$ & 7 & $1(1.5)$ \\
\hline
\end{tabular}

Table 2 provides the case study sample as derived from learners aligned to their class average in PIRLS 2006 and further stratified by language of instruction. Approximately 70\% of learners tested in English were in English First Language (EFL) classes where the class average was below the PIRLS international benchmarks and all learners tested in an African language were in English Additional Language (EAL) classes with an average below the international benchmark. A very small percentage of learners were in classes where the class average reached the Low, Intermediate or High international benchmark. No learners were in classes with an average at the Advanced international benchmark (Zimmerman, 2011). Given the learners' lack of class average representation at the international benchmarks, national benchmarks had to be created to allow for greater insight into group variations between classes. This led to seven profile samples iii from which to select case study schools with performances aligned with each of the PIRLS 2006 international and South African benchmarks. Schools in Gauteng province ${ }^{\mathrm{iv}}$ were approached for participation. 
Table 2: Percentage of learners according to PIRLS 2006 class benchmarks per EAL and EFL class reclassification (Zimmerman, 2011: 93)

\begin{tabular}{|c|c|c|c|}
\hline $\begin{array}{c}\text { PIRLS 2006 } \\
\text { international } \\
\text { benchmarks }\end{array}$ & $\begin{array}{c}\text { South African Grade 4 } \\
\text { learners in classes with } \\
\text { average at each benchmark } \\
\text { Median \% (SE) }\end{array}$ & $\begin{array}{c}\text { Case study EFL } \\
\text { sample reaching } \\
\text { benchmarks } \\
\text { Median \% (SE) }\end{array}$ & $\begin{array}{c}\text { Case study EAL } \\
\text { sample reaching } \\
\text { benchmarks } \\
\text { Median \% (SE) }\end{array}$ \\
\hline $\begin{array}{c}\text { Below } \\
\text { international } \\
\text { benchmarks }\end{array}$ & $93(1.4)$ & $70(5.3)$ & 100 \\
\hline $\begin{array}{c}\text { Low } \\
(\mathbf{4 0 0 - 4 7 4 )}\end{array}$ & $3(1.1)$ & $11(4.3)$ & 0 \\
\hline $\begin{array}{c}\text { Intermediate } \\
(\mathbf{4 7 5 - 5 4 9 )}\end{array}$ & $3(1.2)$ & $13(5.0)$ & 0 \\
\hline $\begin{array}{c}\text { High } \\
\mathbf{( 5 5 0 - 6 2 4 )}\end{array}$ & $1(1.0)$ & $6(3.9)$ & 0 \\
\hline $\begin{array}{c}\text { Advanced } \\
(\mathbf{6 2 5 + )}\end{array}$ & 0 & 0 & 0 \\
\hline
\end{tabular}

As evidenced in Table 2 above, only one percent of learners were in classes in schools where the Grade 4 class which completed the PIRLS 2006 reading literacy assessment had a class average aligned to the PIRLS High international benchmark of 550 to 624 on the achievement scale. All of these learners were in classes with EFL medium of instruction from Grade 1. Ultimately, this means that these learners were among a very small group of learners in the country who could be considered to have successful reading literacy levels as determined by their class average achievement in the PIRLS 2006.

A school in Gauteng province with such a class average was purposively selected on the basis of this 2006 Grade 4 class average at the PIRLS High international benchmark for participation in the case study phase of the research and research permission was received. Highlighting the privileged status of the school which makes it an outlier from most South African schools, the school was an exclusive private school situated in an affluent urban neighbourhood in Johannesburg, serving learners from privileged socioeconomic backgrounds. The average class size at the school ranged between 20 and 23 learners and the school catered for learners from Grade 0 to Grade 12. Schools fees for Grade 4 in 2009 were R46 769. A total of 473 learners attended the primary school in 2009 and there were 38 teachers on the staff. It was estimated that the pupil-to-teacher ratio at the school was about 19:1. The vast majority of teachers and learners at the school were white South Africans from a particular cultural background, ${ }^{\mathrm{V}}$ but learners from other races and cultural backgrounds were present as well. In terms of socioeconomic background, the principal of the school reported that, in general, the learners from the school were from middle- to upper-class financial backgrounds. Approximately $26-50 \%$ of the learners were reportedly from economically affluent homes and $0-10 \%$ of learners from economically disadvantaged homes. Less than $10 \%$ of the learners did not have the language of teaching as a first language. An index of availability of school resources compiled via responses to the PIRLS school questionnaire was high, as were indices of the principal's perception of school safety and of school climate. The learners at the school were depicted as very spontaneous, confident, resilient, active and enthusiastic, and were outspoken and challenging in a respectful way. In specific reference to reading at the school, a minimal number of learners still needed to decode during the 
Intermediate Phase grades. Also, a small number of learners at this phase still pointed with their fingers, sounded out words and/or needed to refer to their phonics chart when reading (Zimmerman, 2011).

\section{Data collection and analysis strategies}

Data were collected from six sources for the PIRLS 2006 benchmark aligned case studies. These included: Grade 4 teacher and head of department interviews; learner workbook reviews; photographs of classroom environments; questionnaires for teachers; and lesson observations. The focus of data collection and reporting for each case study was Grade 4, which was the target grade for the PIRLS 2006. At the time of data collection, it was ascertained that the highest performing case study school (as aligned to class average on the PIRLS 2006 High international benchmark discussed above) had so-called Literacy or Language subject area leaders for each phase in the school. Therefore, interviews were conducted with the Intermediate Phase Literacy leader and, although the focus of the study was Grade 4, an interview was also conducted with the Foundation Phase Literacy leader together with the Grade 3 teacher. The rationale for this was to collect additional data from the Foundation Phase to shed further light on the nature of the success of learners' reading performance at Grade 4 level, although it was not the focus of the study's original research questions. In this paper, selected findings derived from the Grade 3 and Grade 4 teacher and Foundation and Intermediate Phase Literacy/Language subject area leader interviews are discussed. Teachers also provided a document that was given to parents to assist with reading at home, which is also reflected on. The interviews were analysed using constructivist grounded theory principles (Charmaz, 2006), organised by the computer-aided qualitative data analysis software Atlas.ti (Zimmerman, 2011).

\section{FINDINGS}

The reading literacy teaching practices at the school stood out as exemplary when compared with the other case study schools (see Zimmerman \& Smit, 2014), as reflected in the international literature on effective schools (Postlethwaite \& Ross, 1992; Lockheed et al., 1991) and in terms of school-level management structures and school-level strategies for reading literacy development. In this section, school-level reading literacy development practices in the form of literacy programme planning, monitoring and collaboration, acrossgrade and -phase reading literacy programme coordination and parental involvement strategies are discussed (Zimmerman, 2011).

\section{Literacy development planning, monitoring and collaboration at the school}

Planning and monitoring of literacy teaching and learning were key activities leading to high levels of accountability in the management structures of the school. Planning and monitoring involved all stakeholders, including the principal of the primary school, grade teachers, Literacy leaders and Language subject area leaders.

The primary school principal had hands-on involvement in strategising teaching:

... our principal ... will bring us feedback from the principals' meetings and she 'll say 'this is what's happening at other schools. Would you like to try it?' So it's quite democratic, there's nothing autocratic. It's not set in stone. So we'll say 'you know we 
tried it. It didn't work. Can we try something else?' (P3, 3:119, 121:121). ${ }^{\mathrm{vi}}$

As part of the overall management of the literacy development programme at the school, each phase had a teacher who took on a key role in monitoring literacy development. There was a Foundation Phase Literacy leader and an Intermediate Phase Language subject area leader. The Foundation Phase Literacy leader's role was to oversee that Grades 1, 2 and 3 were 'running smoothly and following through... [by checking] scope... sequence [of curriculum implementation] and follow-up, [and making sure there was] not repetition' (P1; 1:1; 2:3). The Literacy leader maintained a global overview of what was happening in the phase for literacy development with each grade teacher communicating with her and vice versa (P11:4:3, 4:5).

The Intermediate Phase Language subject area leader indicated that she served in a mentoring and advisory capacity for fellow teachers (P3, 3:20, 29:31). There were monthly grade-based planning meetings between the subject area leader and the teachers. At these meetings, book and assessment quality control occurred, feedback was given on cluster meeting attendance, ideas were shared, goals were set for teaching and reflection on the success of previous approaches took place. Teaching methods, specifically new methodologies, were discussed and flexible problem-solving was employed to explore options. Besides active involvement in planning for learning at the school, the subject area leader acted as chief moderator of assessments across the grades in the phase (P3, 3:13, 28:35).

Any programme purchased at the school for learners' reading literacy development was reviewed by school management prior to approval for teachers to purchase it. Management would then request feedback from teachers and learners about their experiences of the programme:

every stakeholder will report back on the success of what has been purchased and then ultimately the subject leader would be responsible then to reporting to the principal of the primary school and then quite regularly a yearly interview with the executive head [happens] where we are questioned on the progress of what has been done. So there's that constant monitoring to make sure that our standards are upheld (P3,21, 122:125).

Another feature of literacy programme planning at the school was 'road mapping', in which staff met to plan for the following year, discussing strategies that worked and those that did not, as well as goals for the future (P3, 33, 47:47). As the Language subject area leader stressed:

There's intense planning and I must say in my thirty-one years of teaching, twenty-one were spent at another school and ten here, I have never in all my talks with other colleagues seen a school that puts so much emphasis into their work structures and the remediation ( $\mathrm{P} 3,3: 183,89: 89)$.

At the school, teacher teamwork was emphasised with teachers' parallel teaching, drawing up assessments and marking. There was an open-door policy in each classroom and colleagues would observe each other's lessons and offer peer critique and support. The subject area leader observed that 'everything is done as a whole. We always emphasise that there is no and I know it sounds clichéd - but that "there is no 'I' in team"' (P3, 3:21, 31:33). As further emphasised by the subject area leader: 
Lately we've really just 'all come to the party'... [teachers] say 'I don't really agree with what you're saying, can we try it this way?'... it's trial and experiment. We [management] don't profess to know everything and ... [the teachers] will say 'sure, let's give it a shot' and we'll reconvene and we'll say 'you know it really didn't work. Are there any other avenues that we can explore?' so it's really superb (P3. 3:26, 43:43).

\section{Reading literacy programme coordination across grades and phases}

The school was the only case study school in the larger study with an active strategy to deal with the coordination of teaching and learning across the phases at the school. Reading literacy teaching took place within a larger school-wide framework for the teaching and promotion of reading literacy development. Reading literacy teaching programmes at each phase in the primary school (including pre-primary) were coordinated to meet the reading literacy requirements for the next grades and phase of schooling. One of the tasks of the Intermediate Phase Language subject area leader was to meet with the Foundation Phase Literacy leader and high school teachers during the school year to ensure that learners entering and exiting the phase would be able to meet the standards of reading literacy development expected of them at the first grade in their next phase of education. Similarly, the Foundation Phase Literacy leader would meet with the pre-primary school teachers and the Grade 4 teachers for the same purposes. The Foundation Phase Literacy leader even attended meetings with the high school so that she could 'see where we are headed to' ( $\mathrm{P} 1$, $1: 22,72: 72)$.

As the Grade 3 Literacy leader explained:

... we liaise with ... the nursery school and with the Grade 4 teachers. So where they've ended off, we follow through and we also let them know each year where we found weaknesses with the children coming up from the pre-primary department. Then what happens with the Grade 4 [teachers], they will liaise with me and with the Grade 3 teachers and they will see where the Grade 3 teachers left off, where they think their strengths were, where their weaknesses are, what they would like them to work on in future (P1, 1:2, 3:3).

The Foundation Phase Literacy leader would make sure that the pre-primary teachers used the same font in their classrooms as used in the Foundation Phase so that learners entering the phase would have exposure. They also sent rhymes to the pre-primary teachers for their learners to learn, which would be continued in Grade 1. The reading system used in the Foundation Phase was also started in the pre-primary so that the children were familiar with the characters and background information on the stories prior to Grade 1.

To enable grade and phase coordination further, teachers undertook 'scoping' of what needed to be covered in a grade and 'sequencing' to ascertain how this scope followed through to the next grade. This meant that, when learners moved to the next grade, the teacher knew what content did not need to be repeated and instead focused only on reinforcement of previously learnt content to avoid unnecessary overlaps in teaching between the grades and to ensure that there was constant progress. This also meant that any new teacher entering the grade would have a file outlining what was expected and could ensure learners' progression ( $\mathrm{P} 1,1: 14$, 29:33; P1, 1:17, 34:41). 
Having such records of what had been taught in each grade with a group of learners also meant that teachers could compare the progress of learners in a grade across years to adapt teaching to the learners in their present class:

If you get a stronger or weaker group... you can see by looking at that scope and sequence, you know 'last year's Grade 3 [learners], we've got this far, this year, we've only got to this level', so it also helps you adjust your standards according to the group of children that you've got... it also helps with the assessment and everything as a teacher then you see that your children are battling to get through like the three aspects that we did last year at this time, then you need to slow down and work at a slower pace. So you adjust your expectations, your standards, your assessments and everything.... And then the teacher will obviously communicate with the teachers in the next grade and say, we didn't cover this, this group was a bit weaker, they didn't get to that. So there is full sequence, and you know the children aren't missing out (P1, 1:17, 34:41).

The tracking of learners' development and progress in a grade and implementation of interventions at lower grades when it was deemed not to be up to standard was also evident:

I think the biggest thing with the reading is reading for meaning, this whole reading comprehension because you know children can decode and read with words from pictures... but in Grade 3, they've got to learn to read for meaning... we found that to be quite a weakness because in... Grade 4, they found that their comprehension skills were very weak. So what we've actually done within Grade 1 now, we've started basic comprehensions as well (P1, 1:10, 18:19).

Changes implemented were tracked across grades over a number of years to see if such changes had made a difference to learners over time (P1, 1:18, 42:43). Assessment was also coordinated across grades. A teacher at the grade would set the assessment obtaining input from a teacher at the grade which followed this grade (P3, 3:13, 28:35). In this way, crossgrade assessment quality control was achieved.

\section{Initiatives for learners' reading literacy development}

The school followed an 'eclectic approach' by varying their strategies to encourage learners to read across the primary school (P6, 6:9, 71:94). Strategies as listed in a school reading strategy document given to parents of learners in Grades 1 to 7 for information purposes included: teaching of sound and word families; spelling scope and sequence; Schonell word lists for spelling; most commonly misspelled words and frequently used words; fiction and non-fiction readers based on a Whole Language Approach; the CAMI literacy programme for reading, comprehension and grammar skills; teacher reading for 10 minutes daily; a compulsory library period for Grade 1 to 4 learners once a week; paired and shared reading; children reading to the teacher at least twice a week in the Foundation Phase; phonemic charts on each learner's desk until the end of Grade 4; and a blocked formal reading lesson where reading strategies were taught. The Grade 1 learners read to the Grade 0 learners in the third term and the Grade 7 learners read to the Grade 1 learners as well (P1, 1:25, 86:86).

The creation of a language-rich environment, using flash cards, labels, current affairs and events in every classroom, was also school policy. Each classroom had an author box wherein 
books from different authors would be placed to introduce learners to different author styles and to encourage a love for and enjoyment of reading'. There was also a reading corner in each class (P6, 6:9, 71:94).

A 'Readathon' was held every year for the Foundation Phase grades and every alternate year for the Intermediate Phase grades. There was a 'character in theme day' held at the school every year, in which learners dressed up as their favourite book character. A literacy quiz was also held every alternate year. Moreover, drama productions of novels were undertaken at the school (P3, 3:123, 127:127).

\section{Parental involvement strategies}

The school was the only one in the sample where teachers had mostly positive views of parental involvement in their children's education. Parents were described in the teacher interviews as enthusiastic with a willingness to attend meetings and work with the staff. This positive parental involvement was likely a result of the school's drive to elicit their involvement. At the beginning of each school year, teachers at the school issued a list of learning area outcomes and expectations of learners to the parents. Additionally, there was a parents' initiation evening for each grade, at which the teachers spoke about their learning areas and expectations, and gave parents clear guidelines about what was expected from them and from their children. Parents were also invited to attend presentations on key learning foci during the course of the year.

Surprisingly, regardless of whether or not parental involvement was experienced as positive, few learners came from a background of literate language exposure at home, as evidenced by the following interview discussion with the subject area leader:

we find very few parents are actually reading to their children. Our children don't know their nursery rhymes [Researcher: That, I was interested in... do you find that they come to school from literate home environments, in terms of a love of reading?]... Absolutely not. Very, very few, very few. (P3, 3:131, 131:133).

As such, it was felt that parents needed 'guidelines as to how to read to their children, what to expect from their children' (P3, 3:152, 157:157), which they received in the form of the school reading strategy document mentioned above. In this document, parents received a list of questions they could ask their children in Grades 1 to 7 after they had finished reading a book. These questions included (P6, 6:2, 49:58):

- Did you enjoy the book? Why?

- Why did you choose it?

- Who were the characters?

- Who was your favourite character? Why?

- How would you describe the character?

- Was there anything about the story that you did not like?

- Are there any words you did not know the meaning of?

- Can you retell what happened in the story?

For Grade 1 specifically, parents received tips, such as: encourage your child to guess what the story is about; praise your child when an idea or word is used that you know will come up 
in the story; get your child to predict what a story is about before reading it; encourage reading from pictures in the story before looking at the print; talk about the start of the story, the ending and the people in the story; and discuss the author and illustrator. The parents were also given a list of basic sight words to reinforce with their children (P6, 6:1, 6:18). For oral reading from Grades 1 to 7 , parents were also given strategies to assist when their child made errors (P6, 6:4, 21:47).

\section{DISCUSSION}

The non-privileged status of the majority of South African schools, managerial ineffectiveness, and lack of parental partnership or initiatives to encourage partnership may play a role in their ineffectiveness. The lack of effective school management could specifically lead to the non-setting of school-level goals for reading literacy, poor teacher collegiality, and lack of coordination of teaching practices across grades and phases, and could lead to curriculum implementation lags (Zimmerman, 2011).

The highest performing PIRLS 2006 case study school profiled in this paper was an exclusive private school with high fees and few, if any, learners who were from economically disadvantaged backgrounds, both aspects likely to play a fundamental role in achievement levels at the school. Nonetheless, the qualitative analysis of reading literacy development practices at the school confirmed that the privileged status of the school and its learners were not the only school characteristics driving high learner achievement. The school management structures and classroom-level learning strategies (see Zimmerman, 2014; Zimmerman \& Smit, 2014) mirrored the characteristics of reading literacy of effective schools outlined in the international school effectiveness literature base (Lockheed et al., 1991; Postlethwaite \& Ross, 1992). Moreover, the detailed information provided by the case study analysis allowed for in-depth understanding of the management and planning structures and strategies that enabled such effectiveness. These management and planning structures and strategies have to date not been evident in the research literature on reading literacy practices in South African primary schools. These structures and strategies are also not apparent in curriculum implementation directives given to schools by the DBE and teachers for reading literacy development. Given the poor reading literacy achievement of the majority of South African learners and the challenges experienced in the teaching of reading literacy, one can surmise that such structures and strategies are likely not present in many South African primary schools.

So, what can be learnt from the structures and strategies at this high-performing school? There is a need for educational policy with clear guidelines on the development, implementation and management of school wide literacy programmes. The strategies at the school are exemplary and can potentially be replicated at other schools. Although a new curriculum (DBE, 2012) has gone a long way in attempting to improve the scope and sequence of curriculum implementation for reading literacy development, the case study school shows that this cannot just be an individual teacher initiative but needs to be a coordinated school level undertaking incorporating feedback systems and accountability. For effective school-wide literacy development, school management teams, including principals, head of departments, subject area leaders and all teachers in every subject, need to be actively involved in goal setting, monitoring and implementation. School management also need to initiate teacher support and mentoring, monitoring of effectiveness of implementation strategies and coordination of literacy programmes across the primary school grades and 
phases. Thus, as suggested in a governmental task team review report (DoE, 2009: 10), principals, heads of department and subject area leaders need clear directives on their roles and responsibilities for curriculum implementation for reading literacy development (Zimmerman, 2011).

Also, more targeted strategies to elicit parental involvement in their child's reading development need to be developed and implemented, as well as initiatives to encourage learners to read created. The DBE's (2015) Read to Lead campaign, which encourages reading in schools and in learners' homes, is a step in the right direction but the guidelines need far more substance than is currently given and need to happen at a policy level rather than just as a campaign.

The gravity of the problem with reading literacy instruction in South African schools may be beyond the scope of district-based DBE support teams to deal with. There is a need for school-based support for reading literacy teaching and learning. The training of reading coaches via postgraduate qualifications for such purposes may be a potential solution. Reading coaches (also referred to as literacy coaches or reading specialists) are involved in teachers' professional development experiences by means of theory, demonstration, practice, feedback and classroom coaching. The primary role of reading coaches is to provide support to teachers for classroom reading instruction. These coaches need to have experience of teaching at the level to which they provide coaching, in-depth knowledge of reading processes and acquisition, assessment and instruction, as well as skill in facilitating teacher reflection, observing, modelling and providing feedback to teachers (IRA, 2004: 4). Teachers with such a specialisation could play a central role in school-level curricular planning and the creation of school wide literacy programmes, monitoring of the coordination of reading instruction and teacher mentoring (Zimmerman, 2011).

Given the passage of time since these case studies were implemented, the challenge now lies with researchers to seek high-performing schools that are representative of the realities of the South African education system but are successful given the contextual challenges faced. As acknowledged in this article, the high-performing school reported on was an outlier, which has to be borne in mind when considering the transferability of the findings to other less privileged school settings. There is of course no one panacea that will fit all schools.

Standards for identifying such high-performing schools for in-depth research representative of the realities of the South African education system need to be carefully considered. The use of results from international comparative studies of educational achievement such as a the PIRLS is one possibility, as demonstrated in the methodology for this article. Our own nascent national assessment systems can also be considered to aid identification of highperforming schools provided the validity and reliability of such assessments are established. As Christie et al. (2007: 31) argue, there are schools that meet their mandates to deliver quality teaching and learning, but the challenge is how to have more of these. The processes and structures at such exemplary schools need to be more closely investigated to enable further insights and policy developments for the improvement of reading literacy practices and management processes in the majority of schools.

\footnotetext{
${ }^{\mathrm{i}}$ Learner performance data for schools with learners tested in Afrikaans were removed from the sample.
} 


\footnotetext{
${ }^{\text {ii }}$ The schools where the language of instruction had not changed at Grade 4 were referred to as English First Language (EFL) schools, and the schools where the language medium had changed, as English Additional Language (EAL) medium schools. Although these EAL learners learn in English as the main language of instruction from Grade 4, the learners were assessed in the language of instruction from Grades 1 to 3, an African language, for PIRLS 2006.

iii Given the learners' lack of class average representation at the international benchmarks, national benchmarks had to be created to allow for greater insight into group variations between classes. Using additional South African benchmarks of 175 and 325 and the PIRLS 2006 Low (400), Intermediate (475) and High (550) international benchmarks, seven educational profiles defined by average class performance on the benchmarks and class language (i.e. EFL and EAL 175, EFL and EAL 325, EFL 400, EFL 475 and EFL 550) were identified for the first phase secondary analysis (Zimmerman, 2011).

iv The EFL schools with performance at 550, 475, 400 and 325 points as well as an EAL school with a performance level at 175 points were sampled from Gauteng. No school at EFL 175 was available to participate in the time allocated for data collection. As the only school in Gauteng which had a class average aligned to the EFL 475 benchmark declined to participate, a school in KwaZulu-Natal meeting this criterion was approached and participated (Zimmerman, 2011).

${ }^{v}$ The cultural background of the learners is not given as this could impact the ethical commitment to confidentiality for the research.

${ }^{\text {vi }}$ For audit trail purposes, each participant comment or quotation is followed by a bracketed reference as to where the data can be found in the Atlas.ti hermeneutic unit in which it is situated. For example, the "P3" in the reference "P3, 3:119, 121:121" refers to primary document number 3; "3:119" refers to code 119 in primary document 3 ; and the numerals "121:121" refer to the line numbers of the verbatim quotations.
}

\section{REFERENCES}

CHARMAZ, K. 2006. Constructing grounded theory. A practical guide through qualitative analysis. Thousand Oaks, CA: Sage Publications.

COLLINS BLOCK, C, M OAKAR \& N HURT. 2002. The expertise of literacy teachers: a continuum from preschool to Grade 5. Reading Research Quarterly, 37(2):178-206. DOI: 10.1598/RRQ.37.2.4.

CHRISTIE, P, D BUTLER \& M POTTERTON. 2007. Report to the minister of education: ministerial committee on schools that work. Available from http://www.education.gov.za/Portals/0/Documents/Reports/Ministerial_Report.pdf?ver=201101-18-115037-907 [Accessed: 31 October 2017].

DEPARTMENT OF EDUCATION (DOE). 2009. Report of the task team review of the implementation of the National Curriculum Statement. Pretoria: DoE.

DEPARTMENT OF BASIC EDUCATION (DBE). 2011. Curriculum and Assessment Policy Statement. Grades R-3.English Home Language. Pretoria: DBE.

DEPARTMENT OF BASIC EDUCATION (DBE). 2015. Read to Lead. Available from http://www.education.gov.za/Home/Read2Lead.aspx [Accessed: 31 October 2017].

HOWIE SJ, E VENTER, S VAN STADEN, L ZIMMERMAN, C LONG, V SCHERMAN \& E ARCHER. 2008. Progress in International Reading Literacy Study 2006. Summary report. South African children's reading literacy achievement. Centre for Evaluation and Assessment, University of Pretoria, Pretoria.

HOWIE, SJ, S VAN STADEN, M TSHELE, C DOWSE \& L ZIMMERMAN. 2012. PIRLS 2011: South African children's reading literacy achievement report. Centre for Evaluation and Assessment, University of Pretoria, Pretoria.

INTERNATIONAL READING ASSOCIATION (IRA). 2004. The role and qualifications of the reading coach in the United States. A position statement of the International Reading Association. Available

from http://www.reading.org/Libraries/Position_Statements_and_Resolutions/ps1065_reading_coac h.sflb.ashx

KLAPWIJK, NM. 2012. Reading strategy instruction and teacher change: implications for teacher training. South African Journal of Education, 32:191-204.

Per Linguam 2017 33(2):36-50

http://dx.doi.org/10.5785/33-2-740 
LEVIN, B. 2006. Schools in challenging circumstances: a reflection on what we know and what we need to know. School Effectiveness and School Improvement, 17(4):399-407. DOI: 10.1080/09243450600743459.

LOCKHEED, ME, AM VERSPOOR, et al. 1991. Improving primary education in developing countries. New York: Oxford University Press for the World Bank.

MULLIS, IVS, AM KENNEDY, MO MARTIN, \& M SAINSBURY. 2006. PIRLS 2006 assessment framework and specifications. Chestnut Hill, MA: TIMSS \& PIRLS International Study Center, Lynch School of Education, Boston College.

POSTLETHWAITE, TN \& KN ROSS. 1992. Effective schools in reading: implications for educational planners. An exploratory study. The Hague: International Association for the Evaluation of Educational Achievement.

PRETORIUS, EJ \& NM KLAPWIJK. 2016. Reading comprehension in South African schools: are teachers getting it and getting it right? Per Linguam, 32(1):1-20. DOI: https://doi.org/10.5785/32-1-627.

PRETORIUS, EJ \& M LEPHALALA. 2011. Reading comprehension in high poverty schools: How should it be taught and how well does it work? Per Linguam, 27(2):1-24.

SAILORS, M, JV HOFFMAN, \& B MATTHEE. 2007. South African schools that promote literacy learning with students from low-income communities. Reading Research Quarterly, 42(3):364-387. DOI: 10.1598/RRQ.42.3.2.

SPAULL, N. 2013. Poverty and privilege: primary school inequality in South Africa. International Journal of Educational Development, 33:436-447. DOI: https://doi.org/10.1016/j.ijedudev.2012.09.009.

VAN STADEN, S \& R BOSKER. 2014. Factors that affect South African reading literacy achievement: evidence from prePIRLS 2011. South African Journal of Education, 34(3):1-9.

ZIMMERMAN, L. 2011. The influence of schooling conditions and teaching practices on curriculum implementation for Grade 4 reading literacy development. Unpublished doctoral thesis. University of Pretoria, Pretoria.

ZIMMERMAN, L, SJ HOWIE \& B SMIT. 2011. Time to go back to the drawing board: organisation of primary school reading development in South Africa. Educational Research and Evaluation, 4:215-232.

ZIMMERMAN, L. 2014. Lessons learnt: observation of Grade 4 reading comprehension teaching in South African schools across the PIRLS 2006 achievement spectrum. Reading and Writing, 5(1):1-9.

ZIMMERMAN, L \& B SMIT. 2014. Profiling classroom reading comprehension development practices from the PIRLS 2006 in South Africa. South African Journal of Education, 34(3):19.

ZIMMERMAN, L \& B SMIT. 2016. Comprehending the macro through the lens of the micro: the use of PIRLS 2006 findings to inform comparative case studies across the South African achievement scale. International Journal of Qualitative Methods, (January-December):1-12.

ZIMMERMAN, L \& SJ HOWIE. 2016. Moving from a discourse of access to reading instructional materials to the management and utilisation thereof: Progress in International Reading Literacy Study at Grade 4 in South Africa. Mousaion, 34(2):31-53.

\section{BIOGRAPHICAL NOTE}

Lisa Zimmerman is a Senior Lecturer at the University of South Africa. Email zimmel@unisa.ac.za 